\title{
Diagnostic value and biological significance of antibody-coated bacteria in urine
}

\author{
C MENGoli, E AROSIO, D BONATO, G SPIAZZI, P PANCERA, G MONTESI, \\ A LECHI, AND LA SCURO
}

From the Istituto di Clinica Medica III and Cattedra di Malattie Infettive, Università di Padova-sede di Verona, Verona, Italy

SUMMARY The incidence of antibody-coated bacteria (ACB) in the urinary sediments as an indication of the site of urinary tract infections (UTI) was investigated in 103 adult subjects with persistent bacteriuria by means of a direct immunofluorescence technique.

ACB were found in 49 of $58(84.5 \%)$ subjects with long-standing upper urinary tract obstruction and in 5 of $45(11 \cdot 1 \%)$ with lower UTI; this difference was statistically significant $\left(\chi^{2}=51 \cdot 79\right.$; $\mathrm{P}<0.001$ ). The group with upper UTI was further subdivided according to renal function (patients with renal insufficiency had both bilateral obstruction and bilateral renal damage); 21 positive results were obtained in $27(77.8 \%$ ) patients with normal renal function, whereas 28 positive cases were observed among $31(90.3 \%)$ patients with chronic renal insufficiency. Thus the degree of renal involvement also seemed to influence the outcome of the test. Within the group of lower UTI, a higher rate of 'false-positive' results was obtained in 14 patients with symptomatic longstanding infection $(21.4 \%)$ than in 31 subjects with asymptomatic bacteriuria $(6.4 \%)$. The three major immunoglobulin classes and the secretory component were studied in 42 cases. Of these, 29 were found to be positive for ACB. The constant presence of $\operatorname{IgA}$ and secretory component on the surface of ACB suggests that the secretory immune system plays an important role in UTI.

The localisation of urinary tract infections (UTI) is an important clinical task. The search for an immune response to the infecting microorganism has repeatedly been proposed as a line of approach to the problem. Several authors have studied the serum specific antibody level in human pyelonephritis and cystitis; however, the attempt to distinguish upper and lower UTI by means of serological methods has been hindered by the common occurrence of false-positive cases (subjects with a lower UTI and a high antibody level) and false-negative cases (subjects with pyelonephritis and a low antibody level). ${ }^{1,2}$

Using an immunofluorescence test, Thomas ${ }^{3}$ and Jones $^{4}$ found antibody-coated bacteria (ACB) in the urinary sediment of a patient with pyelonephritis but not of those with lower UTI; they ascribed the finding of ACB to a local production of urinary antibody, ${ }^{3}$ possibly in the kidney itself. ${ }^{4}$

Received for publication 20 September 1979
The diagnostic value of this test to determine the site of UTI has been evaluated by several authors. ${ }^{5-14}$ On the whole, the clinicopathological correlation was confirmed by most investigators on qualitative grounds, but its extent (for example, the incidence of false-positive and false-negative results) varied considerably.

In this study we have looked for both a further evaluation of the diagnostic potential of the test and for an investigation of the biological meaning of ACB in human UTI.

\section{Material and methods}

Altogether 103 adult patients with persistent bacteriuria ( $\geqslant 10^{5} \mathrm{CFU} / \mathrm{ml}$ in at least two consecutive urinary specimens) were studied. They have been grouped according to the following criteria.

GROUP 1

This group comprised 58 subjects with chronic obstructive pyelonephritis. The diagnosis was based 
on microbiological grounds (the aforementioned persistent significant bacteriuria) and on both clinical and pyelographic evidence of long-standing upper urinary tract obstruction. Patients not fulfilling these criteria were discarded from the study. Therefore, so-called non-obstructive ('primitive') pyelonephritis was not taken into account. On these grounds, renal biopsy appeared unnecessary to confirm the diagnosis and was never performed.

To assess the influence of the extent of renal parenchymal involvement in determining the outcome of the test, we divided this group into two subgroups according to the absence (subgroup 1a, 27 subjects) and the presence (subgroup $1 \mathrm{~b}, 31$ subjects) of chronic renal insufficiency. This was demonstrated by a persistently elevated serum creatinine concentration $(\geqslant 1.3 \mathrm{mg} / \mathrm{dl}$, normal values for our laboratory $=0.5-1 \cdot 2 \mathrm{mg} / \mathrm{dl}$ ).

\section{GROUP 2}

This group comprised 45 subjects with a lower UTI; they had both a normal renal function and a normal pyelographic appearance of the upper urinary tract. Of these patients, 31 had an asymptomatic bacteriuria (subgroup $2 \mathrm{a}$ ), whereas the remain- ing 14 patients had a long-standing symptomatic lower UTI due to either prostatic hypertrophy or anatomical bladder abnormalities (mostly neoplasms, diverticula, and calculi) (subgroup 2b).

ACB were sought by means of the direct immunofluorescence technique (Fig. 1) described by Thomas et al. ${ }^{14}$ with slight modifications. Human immunoglobulin covering the bactcrial cells in urinary sediments was detected in all cases with a fluoresceinconjugated anti-human immunoglobulin serum from sheep (Wellcome).

In 42 cases $(27$ patients with pyelonephritis and 15 with lower UTI) the same technique was used to detect the following human serum proteins: IgG, $\operatorname{IgA}, \operatorname{IgM}, \mathrm{C}_{3}$, and fibrinogen by means of specific fluorescent sera from sheep (Wellcome); in the same cases, urinary bacteria were also examined for the presence of secretory component on their surface with an indirect technique: an anti-human secretory component serum from rabbit (Behringwerke) and a fluorescent anti-rabbit-gammaglobulin serum from goat (Behringwerke) were employed for this purpose. The binding specificity of fluorescein-labelled anti-human immunoglobulin serum was checked by competitively blocking the reaction by means of

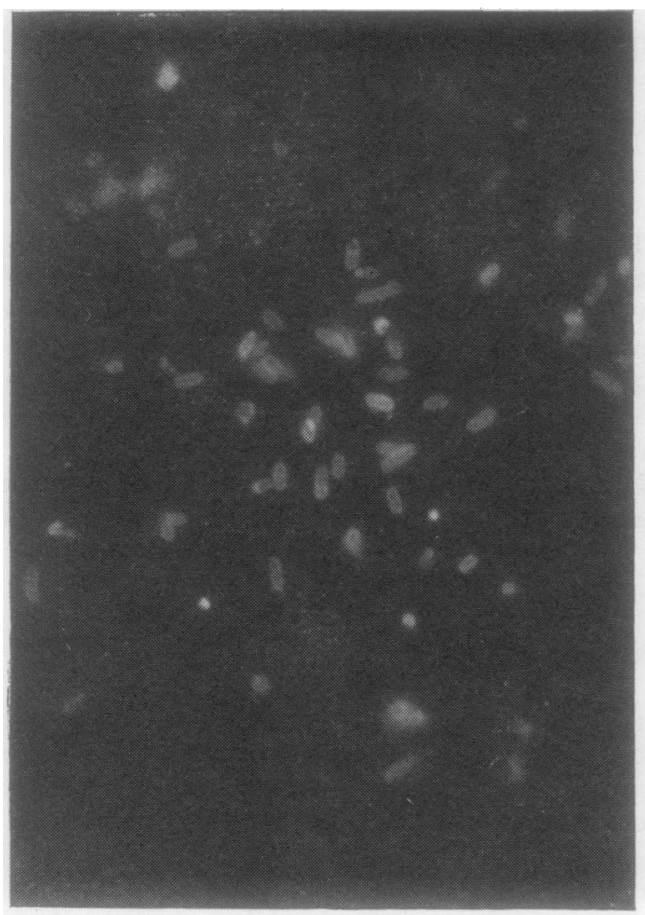

(a)

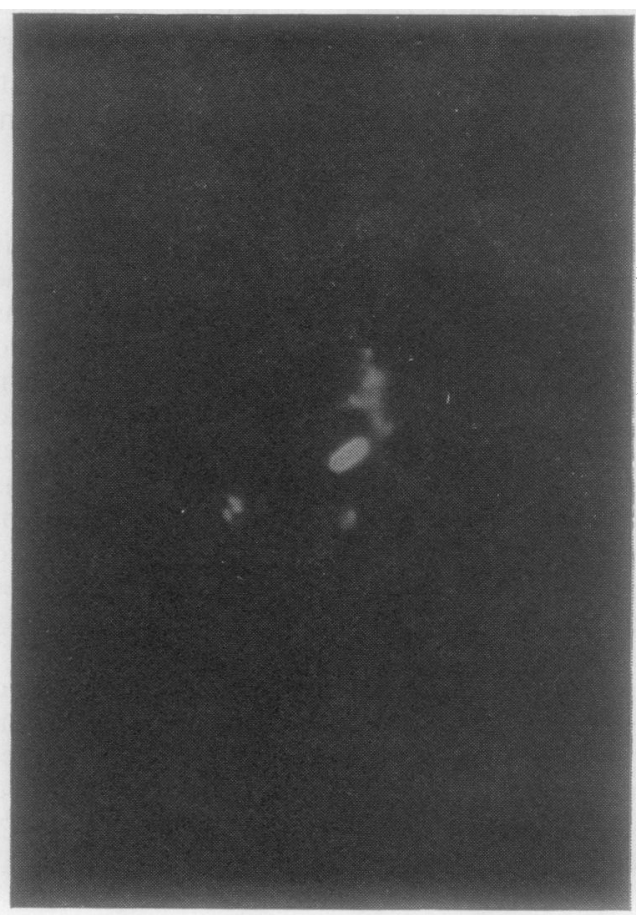

(b)

Fig. 1 (a and b) Fluorescent bacteria (Leitz Orthoplan $\times 1000)$. 
previous incubation with a non-fluorescent antihuman immunoglobulin serum from rabbit (Coombs' serum). The specificity of the secretory component detection was checked in two ways: (1) by performing the whole indirect immunofluorescence technique on the infecting bacterial strain as isolated on a solid culture medium; and (2) by incubating the urinary sediment bacteria with a fluorescent antirabbit immunoglobulin only. The criteria used by Jones $^{15}$ have been employed for defining a urine specimen positive for ACB. The differences between groups 1 and 2 , between subgroups $1 \mathrm{a}$ and $1 \mathrm{~b}$, and between subgroups $2 a$ and $2 b$ have been evaluated statistically by means of the $\chi^{2}$ test with Yates' correction.

\section{Results}

Forty-nine of the 58 subjects in group $1(84.5 \%)$ and 5 of the 45 subjects in group $2(11 \cdot 1 \%)$ were positive. This difference was statistically significant $\left(\chi^{2}=\right.$ 51.79; $\mathrm{P}<0.001$ ).

Twenty-one positive cases were recorded in subgroup 1a ( $77.8 \%$ ), whereas 28 positive cases were observed in subgroup $1 \mathrm{~b}(90.3 \%)$ (Table 1$)$. This difference was not statistically significant.

Table 1 Results obtained in 103 patients with upper and lower UTI by means of a polyvalent, not class-specific, anti-human Ig serum

\begin{tabular}{lcc}
\hline Group* & \multicolumn{2}{l}{ No. of patients } \\
\cline { 2 - 3 } & Total & Positive \\
\hline Upper UTI & 58 & $49(84 \cdot 5)$ \\
Subgroup 1a & 27 & $21(7 \cdot 7 \cdot 8)$ \\
Subgroup 1b & 31 & $28(90 \cdot 3)$ \\
Lower UTI & 45 & $5(11 \cdot 1)$ \\
Subgroup 2a & 31 & $2(6 \cdot 4)$ \\
Subgroup 2b & 14 & $3(21 \cdot 4)$ \\
\hline
\end{tabular}

*Subgroup 1a: pyelonephritis with normal serum creatinine Subgroup $1 \mathrm{~b}$ : pyelonephritis with increased $(1 \cdot 3 \mathrm{mg} / \mathrm{dl})$ serum creatinine

Subgroup 2a: asymptomatic bacteriuria

Subgroup 2b: symptomatic lower UTI

Percentages are given in parentheses.

Two positive cases in subgroup $2 \mathrm{a}(6.4 \%)$ and three positive cases in subgroup $2 b(21.4 \%)$ were found. This difference also was not significant.

Of the 42 patients who were tested with both the six monospecific sera and the anti-human immunoglobulin serum, 29 ( 25 patients with pyelonephritis and 4 with lower UTI) stained positively with the latter. Among these 29 samples, IgG was found in 28 cases, $\operatorname{IgA}$ in all cases, IgM in three cases, and secretory component was always present. Neither $C_{3}$ nor fibrinogen was ever detected (Table 2). In the 13 subjects negative for anti-human immuno-
Table 2 Results obtained with a panel of six monospecific sera in 29 cases which reacted positively to a polyvalent anti-human Ig serum

\begin{tabular}{lcc}
\hline & \multicolumn{2}{c}{ Positive cases } \\
\cline { 2 - 3 } & No. & $\%$ \\
\hline IgG & 28 & $96 \cdot 5$ \\
IgA & 29 & 100 \\
IgM & 3 & $10 \cdot 3$ \\
SC & 29 & 100 \\
C $_{3}$ & 0 & 0 \\
Fibrinogen & 0 & 0 \\
\hline
\end{tabular}

$\mathrm{SC}=$ Secretory component

globulin ( 2 patients with upper and 11 with lower UTI) all monospecific sera also reacted negatively. In addition, all of the above specificity controls were negative.

\section{Discussion}

Our results confirm that the detection of ACB by means of the direct immunofluorescence test is positively correlated with upper UTI; however, a substantial number of false-positive $(11.1 \%)$ and false-negative $(15.5 \%)$ cases have been recorded. A better correlation was obtained by Thomas, ${ }^{3,14}$ Jones, ${ }^{4}$ and other investigators. ${ }^{5,10,12}$ A positive correlation, although less strong, was found by other authors. ${ }^{6,7,8,11}$ Less satisfactory results have been found by Rumans and Vosti, ${ }^{13}$ whereas Hellerstein ${ }^{9}$ failed to attain a statistically significant correlation between the outcome of the test and the seat of UTI. The differential incidence of falsenegative cases in the two subgroups into which subjects with upper UTI have been subdivided according to renal function suggests, even though it does not prove, that the presence of ACB does not depend simply on the seat of bacterial growth but also on the degree of renal parenchymal involvement.

The existence of a distinct immune system common to external secretions, indicated as the secretory immune system, was demonstrated by the discovery that $\operatorname{IgA}$ is the predominant immunoglobulin in many secretions, in contrast to its relatively low concentration in serum (compared to IgG). Secretory $\operatorname{Ig} \mathbf{A}(\operatorname{Ig} \mathbf{A})$ is composed of a polymeric IgA (mainly a dimer), a molecule of $\mathbf{J}$ chain, and a molecule of secretory component. Free secretory component is able to complex in vitro with polymeric $\operatorname{IgA}$ with a mechanism of disulphide interchange with $\mathbf{J}$ chain. Polymeric $\operatorname{IgA}$ is produced and released by plasma cells located in the lamina propria of mucous membranes. Secretory component is produced by epithelial cells and may act as a receptor protein, complexing with polymeric IgA The complex allows 
IgA transport across the epithelial barrier into the lumen. ${ }^{16}$

Whereas a large mass of information concerning the gut-associated immune system is now available, ${ }^{17}$ far less is known about any local immune system associated with the urinary tract. SIgA has been found in normal urine ${ }^{18}$ and has been shown to reach high levels in children with recurrent UTI. ${ }^{19}$ On the other hand, local production of IgG antibody with protective properties has also been demonsirated in experimentally infected kidney and bladder. ${ }^{20}$ Our study confirms these earlier findings by means of a different approach, the immunofluorescence technique, showing the constant presence of IgA and secretory component on ACB in urinary sediment.

Two hypotheses explain the presence of ACB in the urine of patients with UTI. Firstly, local antibody production can be assumed to take place predominantly or exclusively in the renal interstitial tissue, where the binding between antibodies and bacteria occurs; therefore, ACB in urinary sediment are markers of pyelonephritis. Alternatively, a major role can be assigned to the secretory immune system, with antibody synthesis in the lamina propria coupled with active transport across the epithelial cells. This process could become operative at any level along the urinary tract. In this context, it is appropriate to recall that the presence of antigen in infected tissues may cause the local accumulation of immunocompetent cells bearing specific antigen receptors. This phenomenon has also been confirmed in an in vitro model. ${ }^{21}$ Moreover, antibody production by the lower urinary tract was demonstrated in vesical 'sweat' of anephric patients ${ }^{22}$ and in experimental animals. ${ }^{20}$

The latter mechanism could explain the existence of a few 'false-positive' cases in the group with lower UTI; on the other hand, the higher frequency of the positive finding of ACB in the group with upper UTI might be explained by a stronger antigenic stimulation in the latter condition.

If we accept the second hypothesis, the presence of specific antibodies in the fluid phase of urine is a preliminary condition for the immune complex formation (ACB, in this case). Whereas some authors failed to detect fluid phase antibodies in the urine of patients with pyelonephritis, Hanson ${ }^{23}$ was able to find them in a large proportion of upper UTI and, less frequently, in lower UTI.

To explain the presence of antibodies in urine, a passive leak from serum cannot at present be ruled out in every case. However, the coexistence of specific antibodies in serum and urine in pyelonephritis has been found to be very inconsistent. ${ }^{4}$

In summary, we favour the local secretory anti- body hypothesis. The strongest proof supporting it is, in our opinion, the substantial number of positive cases reported in lower UTI. Most of the 'falsepositive' results were found in lower UTI with either deep tissue involvement, as in prostatitis, ${ }^{24}$ or with long-standing bladder infection, as in bladder diverticula, bladder papilloma, or neurogenic bladder. ${ }^{25,26}$ In this regard, the finding of secretory $\operatorname{IgA}$ on bacteria in UTI is a further confirmation of this local immune mechanism.

In conclusion, local immune response in UTI merits great interest and further investigation.

\section{References}

${ }^{1}$ Fries D, Delavelle F, Mathieu D, Jacques L. Production d'anticorps sériques et urinaires au cours des pyélonéphrites. Nouv Presse Méd 1977;6:2227-2231.

2 Percival A, Brumfitt W, De Louvois J. Serum-antibody levels as an indication of clinically inapparent pyelonephritis. Lancet 1964;2:1027-1033.

${ }^{3}$ Thomas V, Shelokov A, Forland M. Antibody-coated bacteria in the urine and the site of urinary-tract infection. N Engl J Med 1974;290:588-590.

${ }^{4}$ Jones SR, Smith JW, Sanford JP. Localization of urinary-tract infections by detection of antibodycoated bacteria in urine sediment. $N$ Engl $\mathrm{J} \mathrm{Med}$ 1974;290:591-593.

${ }^{5}$ Fadda G, Allevato F, Ronzoni F, Schito GC. Significato diagnostico della presenza di anticorpi sulla superficie di batteri contenuti nel sedimento urinario. Atti XVII Congr Naz Soc Ital Microbiol 1975; Padova, 511-516.

${ }^{6}$ Fries D, Krembel C, Delfraissy JF, Jacques L, Delavelle F, Arvis G. Étude en immunofluorescence de la bactériurie. Nouv Presse Méd 1975;4:2179-2182.

7 Galland L. Kass's criterion for U.T.I. (Letter). Lancet 1976;1:910.

${ }^{8}$ Gonick P, Falkner B, Schwartz A, Pariser R. Bacteriuria in the catheterized patient. Cystitis or pyelonephritis? JAMA 1975;233:253-255.

${ }^{9}$ Hellerstein S, Kennedy E, Nussbaum L, Rice $K$. Localization of the site of urinary tract infections by means of antibody-coated bacteria in the urinary sediments. J Pediatr 1978;92:188-193.

${ }^{10}$ Kohnle W, Vanek E, Federlin K, Franz HE. Lokalization eines Harnwegsinfectes durch Nachweis von antikörperbesetzten Bakterien im Urin. Dtsch Med Wochenschr 1975;100:2598-2602.

${ }^{11}$ Mobilio G, Borsatti A, Conventi L et al. Immunofluorescenza batterica nella diagnostica delle batteriurie. Atti XLIX Congr Ital Urol 1976;2:171-180.

12 Moroni M, Privitera G. Kass's criterion for U.T.I. (Letter). Lancet 1976;1:909-910.

${ }^{13}$ Rumans LW, Vosti KL. Antibody-coated bacteria (Letter). JAMA 1977;237:531.

14 Thomas VL, Forland M, Shelokov A. Antibodycoated bacteria in urinary tract infection. Kidney Int $1975 ; 8: S 20-S 22$. 
15 Jones SR. Antibody-coated bacteria in urine (Letter). N Engl J Med 1976;295:1380.

${ }^{16}$ Hauptman SP, Tomasi TB. The secretory immune system. In: Fudenberg HH, Stites DP, Caldwell JL, Wells JV, eds. Basic and Clinical Immunology. Los Altos, California: Lange Medical Publications, 1976;170-181.

17 Waksman BH, Ozer H. Specialized amplification elements in the immune system. The role of nodular lymphoid organs in the mucous membranes. Progr Allergy 1976;21:1-113.

${ }^{18}$ Bienenstock J, Tomasi TBJr. Secretory $\gamma \mathrm{A}$ in normal urine. J Clin Invest 1968;47:1162-1171.

${ }^{19}$ Uehiing DT, Steihm ER. Elevated urinary secretory IgA in children with urinary tract infection. Pediatrics $1971 ; 47: 40-46$.

:20 Záruba K, Vejbora O, Chobola M. The effect of preliminary sensitization and immunization on bacteriuria in rabbits with experimental pyelonephritis. Clin Exp Immunol 1971;9:399-405.

${ }^{21}$ Ponzio NM, Chapman JM, Thorbecke GJ. Effect of antigen on localization of immunologically specific
B cells. Adv Exp Med Biol 1976;73B:65-75.

${ }^{22}$ Feldman BH, Herdman R, Hong R. Local immunomechanism of the urinary tract. Invest Urol 1971; 8:575-582.

${ }^{23}$ Hanson LA, Ahlstedt S, Fasth A, et al. Antigens of Escherichia coli, human immune response, and the pathogenesis of urinary tract infections. $J$ Infect Dis 1977;136:S144-S149.

${ }^{24}$ Jones SR. Prostatitis as cause of antibody-coated bacteria in urine (Letter). N Engl J Med 1974;291: 365.

${ }^{25}$ Boivison A, Guibert J, Acar JF. Bactéries urinaires enrobées d'anticorps. Aspect diagnostique et évolutif. Path Biol 1976;24:695-698.

${ }^{26}$ Thorley JD, Barbin GK, Reinarz JA. The prevalence of antibody-coated bacteria in urine. $\mathrm{Am} \mathrm{J} \mathrm{Med}$ Sci 1978;275:75-80.

Requests for reprints to: $\operatorname{Dr} C$ Mengoli, Istituto di Clinica Medica III, Università di Padova, 37100 Verona, Borgo Roma, Italy. 